\title{
The RoboSTE[M] Project: Using Robotics Learning in a STEM Education Model to Help Prospective Mathematics Teachers Promote Students' 21st-CenturySkills
}

\author{
Adi Nur Cahyono, Mohammad Asikin and Muhammad Zuhair Zahid \\ Universitas Negeri Semarang, Indonesia \\ https://orcid.org/0000-0002-9469-524X \\ https://orcid.org/0000-0003-1121-3629 \\ https:/ / orcid.org/0000-0001-5830-7599 \\ Pasttita Ayu Laksmiwati \\ SEAMEO Regional Centre for QITEP in Math, Indonesia \\ https://orcid.org/0000-0002-8162-0206 \\ Miftahudin \\ SMPN 28 Semarang, Indonesia \\ https://orcid.org/0000-0002-8793-0547
}

\begin{abstract}
Teacher education institutions play a strategic role in preparing prospective mathematics teachers with 21st-century skills to teach mathematics in schools. This study aimed to explore how mathematics lectures employing robotics in a STEM (Science, Technology, Engineering, and Mathematics) education approach can contribute to the preparation of prospective mathematics teachers with 21st-century skills to teach mathematics in schools. The research was conducted through a project called the RoboSTE[M] Project, in three stages: pre-development, development, and field experiment. The project was run to encourage prospective mathematics teachers to arrange mathematical activities for mathematics learning with a STEM education approach using robotics. The findings indicated that the model, lab and online modules developed and implemented in this project succeeded in supporting the ability of prospective mathematics teachers to design a mathematics learning environment with a STEM-influenced robotics approach that has the potential to support students' 21st-century skills. This study has contributed to answer the problem regarding how to provide crosscurricular activities for STEM education by implementing STEM in an integrated manner in schools, including lack of training for teachers, which will translate STEM in the lesson plans. This research shows that teacher education programmes can provide adequate training for pre-
\end{abstract}


service teachers in practising STEM education in mathematics classroom. This study fills in the gaps by focusing on designing a lecture model with a "STEM Robotics" approach for prospective mathematics teachers and their students and to explore its potential to promote prospective mathematics teachers' 21st-century skills.

Keywords: mathematics learning; STEM; robotics; 21st-century skills

\section{Introduction}

Technological developments in the Industrial Revolution Era 4.0 have changed the way of life, study and work (Christensen \& Eyring, 2011) which has an impact on the changing needs of skills in the 21st century. This revolution has encouraged the birth of network-based education. Seeing the characteristics of students today as a post-millennial generation who are very familiar with technology is a potential that needs to be managed to improve the academic quality of learning in schools. Therefore, innovations are needed to utilise the potential and existing systems to encourage students to have 21st century competencies and to become lifelong learners by utilising technology in their academic activities. The PISA 2018 results showed that only 1\% of students in Indonesia who were subjected to international assessment had reached Level 5 (out of 6; OECD average at Level 5: $11 \%)(O E C D, 2019)$. This result shows that very few Indonesian students are able to solve the problems with modelling the situations and use appropriate strategy in solving problems. These PISA results are undoubtedly worrying since the abilities PISA assesses are essential for students to face life in the 21st century.

Education plays an essential role in preparing students to adapt to the work environment and employment requirements of the 21st century (Ananiadou \& Claro, 2009; Gravemeijer et al., 2017). Soland et al. (2013) mention three categories of 21st-century competencies: cognitive competencies, interpersonal competencies and intrapersonal competencies. Cognitive competencies consist of cognitive things that must be mastered (including mathematics, language, art), academic abilities, as well as skills for thinking critically and creatively. Interpersonal competencies include communicating and building collaboration with others, leadership abilities, and awareness of the global situation. Intrapersonal competencies consist of a growth mindset, the ability to learn how to learn, intrinsic motivation, and determination and grit (Soland et al., 2013). Twenty-first-century skills can be broken down into three groups: skills for learning and encourage innovation, skills for being a digital-literate person, and skills to deal with career and everyday life problems. These skills must be acquired by Indonesian citizens to help them compete in the global world. Several

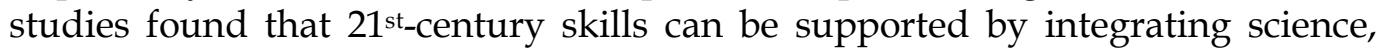
technology, engineering and mathematics (STEM) in comprehensive learning activities (Bergsten \& Frejd, 2019; Frejd, 2017; Kertil \& Gurel, 2016). In the same vein, Beatty (2011) and Stohlmann et al. (2014) together stated that STEM provides many benefits for education.

STEM education has been accepted by several countries and it became popular as a beneficial learning approach (al Murshidi, 2019; Groen et al., 2015; Razali et al., 
2020). STEM education is an interdisciplinary approach to learning in which rigorous academic principles are mixed with real-life lessons in a way that connects the classroom, the environment, the job and the global sector, providing a modern economic literacy that helps learners grow and succeed (Holmlund et al., 2018). Furthermore, teaching STEM purposes to help students working with real-world activities and increases students' performance in learning (Bicer et al., 2017; Jolly, 2016; Li et al., 2019). The STEM curriculum is defined by teaching strategies that inspire students to study science and mathematics, student learning through interdisciplinary experiences relevant to real-world scenarios, problemand project-based learning, advancement of expertise in the 21st century, cooperation with STEM experts, and the use of emerging technology in classroom activities (Bergsten \& Frejd, 2019).

There are two approaches that can be used to develop STEM education: designing fresh curriculum and incorporating STEM practices into the current curriculum. The latter method has multiple integration stages: disciplinary, multidisciplinary, interdisciplinary, and transdisciplinary integration (Bergsten \& Frejd, 2019; English, 2016; English \& King, 2019; Vasquez et al., 2013). Tool-based pedagogy connects classroom activities across STEM disciplines, all four of which will use resources to mould material ideas and principles. Aspects of mathematical modelling in mathematics and inquiry-based learning in science becomes essential starting points for developing STEM pedagogy (Leung, 2019). Several studies discussed that there is another approach called engineering design process (EDP) which is identified as a significant approach in the implementation of STEM (English \& King, 2015; Hafiz \& Ayop, 2019; Li et al., 2019). EDP exaggerates a systematic way in solving open-ended problems in STEM activities by designing solutions (Jolly, 2016; Lockledge \& Salustri, 1999), and the process consists of defining and delimiting problems, designing solutions, optimising the solutions by refining solutions and improving the final design (English \& King, 2015; Jolly, 2016; Siew, 2017; Yata et al., 2020. By implementing EDP, students are facilitated to develop the 21st century skills, such as problem solving, critical thinking, communication, and self-confidence (Rackov \& Knežević, 2017; Stohlmann et al., 2014; Syukri et al., 2018).

Robotics is an outstanding platform for science and engineering and a persuasive subject for all ages (Mataric, 2004). The use of robotics facilitates the integration of science, technology, engineering and mathematics (Altin \& Pedaste, 2013; Barker et al., 2008; Mataric et al., 2007). Robotics can facilitate both the application of engineering and technological concepts in the real world and minimisation of the abstracts of science and mathematics (Nugent et al., 2010). Forsström and Kauffman (2018) found that $40 \%$ of the articles which discussed the potency of programming in mathematics education for students in the age 6-16 employed robotic and its variance (e.g., Lego Mindstorm) to promote programming activities in mathematics learning. It is necessary to develop a new didactic approach to improve STEM skills among young people by optimising the use of robots in learning. Furthermore, exploring the potential of robotics in multidisciplinary learning can be effective to encourage students and student 
creativity, leading to more entrepreneurial, industrial and collaborative research in the STEM field.

The problem faced is how to provide cross-curricular activities for STEM education by implementing STEM in an integrated manner in schools (Corlu et al., 2014; Honey et al., 2014), including lack of training for teachers, which will translate STEM in the lesson plans (Al Murshidi, 2019). In curricular activities, prospective mathematics teachers need to be taught and trained to have the ability and skills to design mathematics learning activity plans by implementing the STEM robotics approach. An activity plan is important to design because it contributes to identifying critical elements in teaching and learning based on theory and provides a description of the effectiveness of learning to be carried out. Through the RoboSTE[M] Project, activity plans are designed by students, then evaluated, refined, re-designed and developed into student worksheets. A bottom-up empirical process was carried out to identify a good activity plan that fits the criteria. Yiannoutsou et al. (2017) developed criteria to identify good activity plans for educational robotics. This consists of two categories, namely prerequisites and main criteria. Prerequisites consist of the topic and include concepts related to STEM or another discipline related to robotics. Other requirements in the prerequisite criteria are the element of constructionist, innovation, the interests of citizens, and the involvement of educational robotic. The main criteria consist of several parameters, namely: context, educational activity, tools, evaluation, sustainability and accessibility. Teacher education programmes are responsible for providing adequate training for pre-service teachers in practising STEM education in the mathematics classroom.

Present pre-service teachers have more capital in using technology for educational purposes since they grew up in the digital age. Although pre-service teachers are more familiar with technology and robotics in classroom, their readiness in implementing STEM robotic education remains unclear. The present study tried to fill in the gaps by focusing on designing a lecture model with a "STEM robotics" approach for prospective mathematics teachers and their students and to explore its potential to promote prospective mathematics teachers' 21st-century skills. Therefore, the research question in this study is how can mathematics lectures with the STEM robotics approach help prepare prospective mathematics teachers with 21st-century skills to teach mathematics in schools?

\section{Method}

To address the research question, research with an exploratory design was conducted through a project called the RoboSTE[M] Project. The exploratory research was utilised to give a good start in finding the grounded theory, because the data collected were emerged in detail, breadth and validity (Stebbins, 2001). As an exploratory, the study involved researchers, prospective teachers, and practitioners (teachers) in all stages. The research was conducted in three stages: pre-development, development, and field experiment. The project was run to encourage prospective mathematics teachers to arrange activities for mathematics learning through a STEM education approach using robotics and to evaluate the results. The project was conducted in the mathematics department of a teacher 
education institution in Indonesia; project participants were 20 prospective mathematics teachers. The study was conducted with activities implemented in a one-semester course.

First, students learn the basic concepts of developing mathematics education media and visual programming. Then, the class discusses STEM and its implementation in mathematics education using robotics. Based on this discussion, students come up with ideas and make activity plans. From the plans, they then, in groups, choose a plan that is realised in the form of student worksheets for learning mathematics with STEM using robotics, through mathematics activities and with mathematical competencies as the main learning outcomes. Researchers observed the students' activities (both classical and teamwork activities) from the first to the sixteenth course sessions and debriefed the students after the course. Notes were made, discussions were recorded, portfolios were stored in an online classroom, and questionnaire responses were collected, and all these data were analysed.

\section{Results}

In the pre-development stage, the activities carried out were preliminary analysis and seminars on STEM and robotics. At this stage, analysis of the Mathematics Education Study Program Curriculum, analysis of instructional media, and achievement of school mathematics learning was also carried out. The analysis was carried out through literature reviews, document analysis and focus group discussions involving researchers, practitioners and related partners.

The activity at the pre-development stage produced a specification of the procedures used for prototype development at the development stage. The prototypes included: a lecture design that employs STEM education using robotics to promote 21st-century skills (called RoboSTE[M] Lecture), the design of a STEM Robotics Laboratory for the development of mathematics education media and mathematics learning practices (called RoboSTE[M] Lab), and a Robotics STEM Education Online Module for mathematics learning (the RoboSTE[M] Online Module). The design also reflects the concept of partnerships with industry, institutions, schools and society.

A series of learning activities using a team-based project method was implemented with the lecture, lab and online modules referred to. A mathematical learning model with a syntax that is integrated with STEM was carried out in several stages in accordance with the result of preliminary analysis and literature study. Students learn concepts related to mathematics education media, the STEM approach, and robotics education for mathematics learning, as well as simple programming using a visual language. There are two main projects undertaken by students in this lecture, in groups: 1) designing STEM mathematics education media by utilising a visual programming language and 2) designing a student worksheet for mathematics learning using the STEM robotics approach. The laboratory and learning activities are shown in Figure 1. 

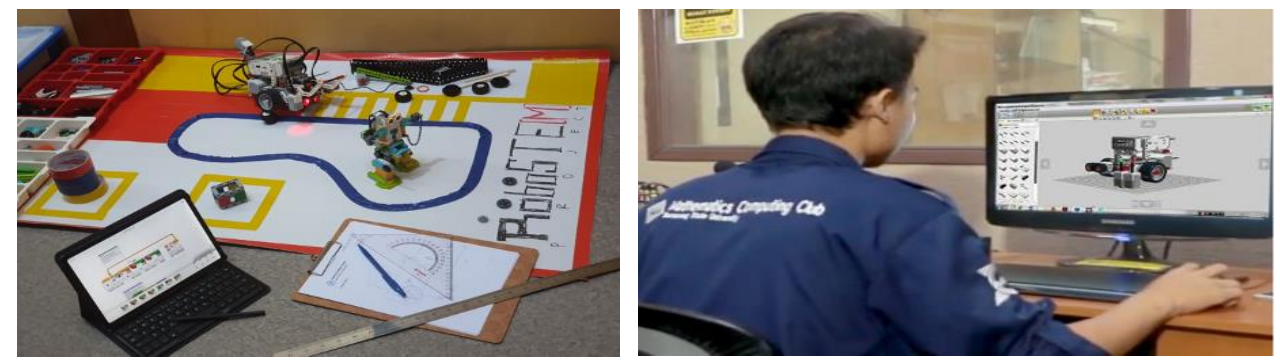

Figure 1: RoboSTE[M] Lab. (Robot: LEGO® \& Software: Virtual Robotics Toolkit)

After coming to understand the concepts of STEM and robotics and their implementation in mathematics learning in the development stage, in the next stage students learn simple programming as a basis for carrying out robotics activities in mathematics learning using the STEM approach. Then, all students carried out a practicum, in which they produced mathematics education media. There were 20 visual media for learning mathematics using the STEM approach developed in this lecture by students, in the form of educational games, interactive media, material exposure, storytelling and the like. One example of such a product produced by students is InteGame; its production process and a sample of the interface are shown in Figure 2.
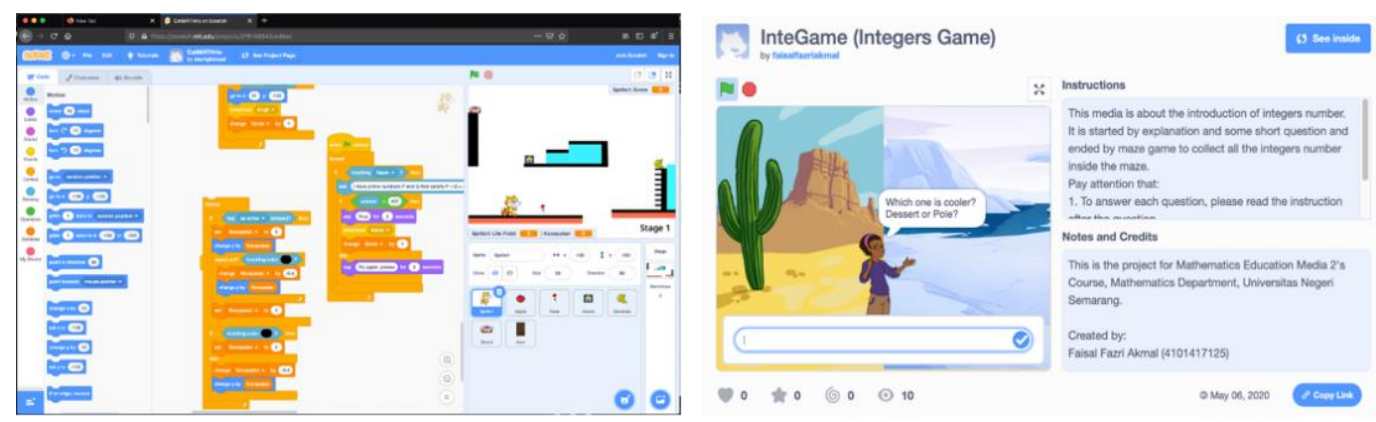

Figure 2: InteGame: Game for integers created by student. (https://scratch.mit.edu)

InteGame is a game for learning positive and negative integers. This game begins with a real situation related to science, namely a problem related to temperature; indicating that the game provides opportunity for learning mathematics and science. The game also allows users to learn technology and engineering through learning mathematics, as they perform simple programming and practise several activities mechanically before reporting the results virtually.

The next project completed by students was designing an activity plan and an accompanying student worksheet. An activity plan is important to learning design because it helps identify important elements in the teaching and learning process based on theory and provides an overview of the expected effectiveness of activities. Through the RoboSTE[M] Project, students learn to design activity plans, which are then evaluated, refined, redesigned and developed into student worksheets. A bottom-up empirical process is carried out to identify a good plan of action that fits the criteria. 
This project resulted in 20 activity plans designed by students. These products reflect that mathematics learning with the STEM approach using robotics varies with topic, target, type of activity and tools used. In general, activities designed with mathematics are more dominant for materials such as geometry, algebra, calculus, statistics and probability, sets, social arithmetic, and others. The targets were junior and senior high school students at various levels. Activities were designed starting by analysing problems, then constructing robots or objects, performing simple programming, and evaluating. The tools used varied; most of them involved Lego Mindstorms EV3.

The 20 activity plans designed by students were widely different in learning models, activities, topics, and tools used. We analysed the data from the student work portfolio by identifying and coding the components of the activity plans that the students had designed. The results are presented in Table 1.

The learning model applied in the learning activities designed in the activity plan is identified based on the syntactic characteristics of certain learning models that appear in the designed activities. These phases may appear as a whole, but may also appear in only a few parts, but the characteristics of the learning model dominate the activities designed.

The results show that activities in most (8) of the activity plans have a character similar to that of the project-based learning model, starting with an essential question and then designing a project that must be done by students. Then, a schedule is made, student activities and project progress are monitored, and the results are assessed, followed by evaluation of the learning experience.

Table 1: Identification of models, activities, topics and tools.

\begin{tabular}{|c|c|}
\hline Criterion & Number of Activity Plans Including It \\
\hline Learning Model & 5 \\
\hline Discovery Learning & 8 \\
\hline Project-Based Learning & 7 \\
\hline Problem-Based Learning & \\
\hline & \\
\hline Activity & 8 \\
\hline Modelling & 3 \\
\hline Designing & 4 \\
\hline Coding & 1 \\
\hline Strategy & 2 \\
\hline Prediction & 2 \\
\hline Exploration & 2 \\
\hline Observation & 1 \\
\hline Counting & 1 \\
\hline Trial and error & 3 \\
\hline Manipulation & \\
\hline Geometry & 9 \\
\hline Sets & 1 \\
\hline Statistics and Probability & 2 \\
\hline
\end{tabular}




\begin{tabular}{|c|c|}
\hline Numbers & 2 \\
\hline Algebra & 5 \\
\hline Trigonometry & 1 \\
\hline \multicolumn{2}{|l|}{ Tool } \\
\hline Simple Machine & 1 \\
\hline Lego Mindstorms EV3 & 11 \\
\hline $\mathrm{mBot}$ & 2 \\
\hline WeDo 2.0 & 2 \\
\hline RoboSim & 1 \\
\hline Arduino UNO & 1 \\
\hline Virtual Robotic Toolkit & 1 \\
\hline
\end{tabular}

In addition to project-based learning, there are seven activity plans whose activities feature a problem-based learning model. The phases that appear include problem orientation, students' organisation, individual and group guided investigations, development and presentation, analysis and evaluation. The third learning model found is discovery learning, in five activity plans. Activity plans in this category contain activities such as stimulation, problem statement, data collection, data processing, verification, and generalisation.

The learning activities designed indicate that modelling activities, encouraging application of mathematical concepts, are dominant over other activities in mathematics learning. Some activity plans also design lessons that facilitate simple programming by students as part of doing projects, solving problems, or performing exploration. Most of the activity plans are used for learning geometry, followed by algebra; however, most or all topics in mathematics can be tackled through learning activities using STEM robotics.

Most of the activity plans are designed to be implemented using the Lego Mindstorms EV3. This tool is suitable for use at the junior and senior high school levels or equivalent, with a target age range of 14-18 years. The use of Lego Mindstorms EV3 makes it easier for students to focus on their mathematical modelling activities, due to less complicated programming requirements.

Two criteria for identifying a good plan of action for robotics learning are provided as developed by Yiannoutsou et al. (2017): prerequisite and main criteria. The results of the activity plan evaluation in terms of the prerequisite criteria are presented in Table 2.

Table 2. Results of activity plan evaluation for prerequisite category

\begin{tabular}{|l|l|l|l|l|l|l|}
\hline Tool & Activity & Assessment & Construction & Innovation & $\begin{array}{l}\text { Real } \\
\text { Impact }\end{array}$ & Education \\
\hline 4.50 & 4.56 & 4.22 & 4.50 & 4.11 & 4.39 & 4.44 \\
\hline
\end{tabular}

Table 2 shows that the activity plan developed has a constructionist element, is innovative and related to the real interests of society and involve the use of robotic for educational purpose. All the STEM subjects are included in the designed activity plan together with robotic topics. Findings indicate that the activity plan 
is not only become predefined guidelines and, therefore, it is also innovative. Results of activity plan evaluation for the prerequisite category showed very high scores for all aspects. The results of the activity plan evaluation based on these criteria in the main categories are presented in Table 3.

Table 3. Results of activity plan evaluation for main category

\begin{tabular}{|l|l|l|l|l|l|}
\hline Context & $\begin{array}{l}\text { Educational } \\
\text { Activities }\end{array}$ & Tool & Evaluation & Continuity & Accessibility \\
\hline 4.50 & 4.50 & 4.56 & 4.39 & 4.11 & 4.28 \\
\hline
\end{tabular}

Table 3 shows that the activity plans designed have strengths in context, educational activities, tools, evaluation, sustainability and accessibility. Overall, the results of the evaluation show that the activity plans capture important elements of the teaching and learning process based on theory and indicate their potential effectiveness as learning tools.

The activity plan is then used as the basis for group development of student worksheets for mathematics learning through a STEM approach using robotics. Worksheets first collect/ provide information on student names, topics, goals, and learning instructions, as exemplified in Figure 3. The initial section also presents an introductory story containing science, technology, engineering, and mathematics content. This section provides information about student learning objectives, introduction and motivation.

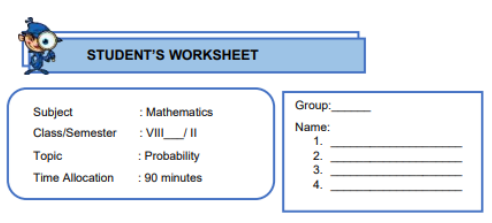

Determine the Sample Space and Probability of an Event

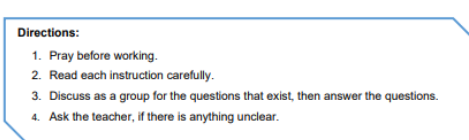

Figure 3: Introduction part of a student worksheet created by students.

Next, students are directed to start their activities. In this section, the problems are presented in the form of interesting contextual cases that challenge students to analyse and prepare strategies. An example is presented in Figure 4. 


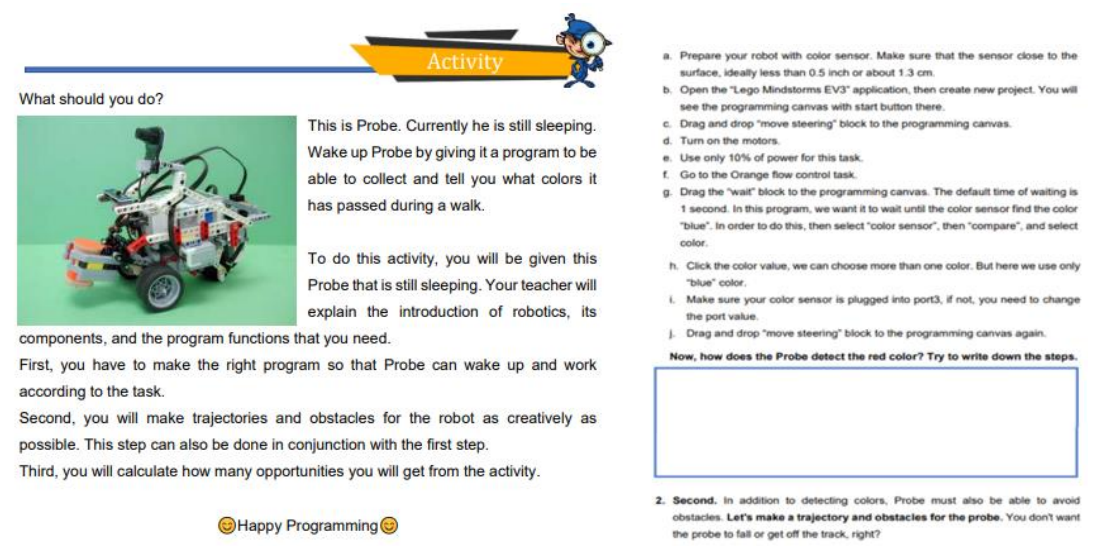

Figure 4: (a) Problem to be solved. (b) Introduction and checking of learning tools and environments. (Robot: LEGO ${ }^{\circledR}$ )

The initial activity here involves understanding and checking of the necessary tools and the learning environment; then, students construct objects and an environment for them (both a physical environment and a digital environment, through programming, as shown in Figure 5). While carrying out physical activities and programming, students also collaboratively conducted the analysis. Finally, students drew conclusions from the concepts being studied.
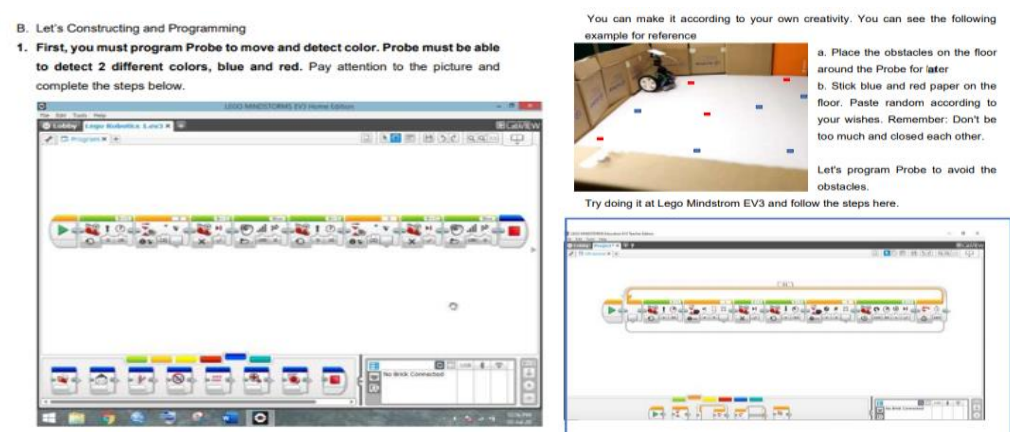

Figure 5: (a) Programming with LEGO ${ }^{\circledR}$ Programmer (Program: LEGO ${ }^{\circledR}$ )

The researchers conducted an analysis of the mathematical content and robotics activities in the activity plans that could support learning using a STEM approach; this was done by identifying the presence of different STEM areas in the activity plan. The results indicate that mathematics is dominant in the learning activities, but other domains also emerge, indicating that the mathematical content and robotic activities support general STEM learning. The potential of an activity plan designed to support students' 21st-century skills was analysed according to the ISTE Standards for Students. The mean scores of the potential activity plan for potential to support students' 21 st-century skills are presented in Table 4.

Table 4: Mean scores of activity plan (Scale 1-5)

\begin{tabular}{|r|r|r|r|r|r|r|}
\hline $\begin{array}{l}\text { Empowered } \\
\text { Learner }\end{array}$ & $\begin{array}{l}\text { Digital } \\
\text { Citizen }\end{array}$ & $\begin{array}{l}\text { Knowledge } \\
\text { Constructor }\end{array}$ & $\begin{array}{l}\text { Innovative } \\
\text { Designer }\end{array}$ & $\begin{array}{l}\text { Computational } \\
\text { Thinker }\end{array}$ & $\begin{array}{l}\text { Creative } \\
\text { Communicator }\end{array}$ & $\begin{array}{l}\text { Global } \\
\text { Collaborator }\end{array}$ \\
\hline 4.30 & 4.35 & 4.2 & 4.45 & 4.15 & 4.3 & 4.1 \\
\hline
\end{tabular}


Table 4 shows that, in general, this activity plan supported students to take advantage of technology to help them take an active role in selecting, achieving and demonstrating competence in terms of their learning objectives, informed by learning science. This is indicated by the Empowered Learner score of 4.30. The Digital Citizen score of 4.32 shows that activity plans have the potential to support students to recognise their rights, responsibilities and opportunities to live, learn and work in an interconnected digital world, in safe, legal and ethical ways. The Knowledge Constructor score of 4.2 means the activity plan supports students to critically curate various resources using digital tools to build knowledge. The Innovative Designer score of 4.45 means that the activity plan supports students to use various technologies in the design process. The Computational Thinker score of 4.15 means that the activity plan supports students to use the power of technology to comprehend problems, propose solutions, as well as evaluate strategies used to solve the problems. The Creative Communicator score of 4.3 means that the activity plan supports students to communicate clearly and express themselves creatively, and the Global Collaborator score of 4.1 means that the activity plan sufficiently supports students to use digital tools to broaden their perspectives.

Based on the results of these studies, it can be shown that 21st-century skills can be enhanced by STEM learning, which provides many benefits for education. These results reinforce the statements and results of previous studies (Bergsten \& Frejd, 2019; Frejd, 2017; Kertil \& Gurel, 2016; National Research Council, 2011; Stohlmann et al., 2014). This approach successfully mixes difficult academic principles and real-life educations as mentioned by Holmlund et al. (2018). This research also shows that STEM helps students working with real-world activities and increases students' performance in learning and inspires students to study science and mathematics, student learning through interdisciplinary experiences relevant to real-world scenarios, problem- and project-based learning, advancement of expertise in the 21st century, cooperation with STEM experts, and the use of emerging technology in classroom activities. This result is in line with previous studies (Bergsten \& Frejd, 2019; Bicer et al., 2017; Jolly, 2016; Li et al., 2019).

In this study, STEM has been implemented with an engineering design process (EDP) approach that consists of defining and delimiting problems, designing solutions, optimising the solutions by refining solutions and improving the final design. The findings indicate that students were encouraged to improve their ability to solve problems, thinking critically, and communicate with peers. This is in line with some of the results of previous studies, such as Stohlmann et al. (2014), Rackov and Knežević (2017) and Syukri et al. (2018).

In this research, robotics has been applied to support the integration of science, technology, engineering and mathematics. This integration is based on references from Mataric et al. (2007), Barker et al. (2008), and Altin and Pedaste (2013). This study has contributed to answer the problem regarding how to provide crosscurricular activities for STEM education by implementing STEM in an integrated manner in schools, including lack of training for teachers, which will translate 
STEM in the lesson plans. This research shows that teacher education programmes can provide adequate training for pre-service teachers in practising STEM education in mathematics classroom. This study fills the gaps by focusing on designing a lecture model with a "STEM robotics" approach for prospective mathematics teachers and their students and to explore its potential to promote prospective mathematics teachers' 21st-century skills. Thus, mathematics lectures with the STEM robotics approach can help prepare prospective mathematics teachers with 21st-century skills to teach mathematics in schools.

\section{Conclusion}

Through the RoboSTE[M] Project in this study, a lecture model, an online module and a laboratory design delivered within the Mathematics Education Study Programme have been developed to prepare prospective mathematics teachers to be ready to teach mathematics using the STEM robotics approach and to be oriented towards 21st-century skills. They were shown to be valid and suitable for application in lectures based on implementation in class, and their potential to promote prospective mathematics teachers' 21st-century skills was explored. The results of implementation show that this lecture activity can support prospective mathematics teachers to plan learning activities and develop student worksheets with the recommended models, for project-based learning, problem-based learning, and discovery learning. Mathematics lessons planned by prospective mathematics teachers with a STEM robotics approach can be designed for a variety of topics, including geometry, sets, statistics and probability, number, algebra, and trigonometry. The activities designed were also varied, and included modelling, designing, coding, strategy, prediction, exploration, observation, counting, trial and error, and manipulation. Further, students can design activities using a variety of tools. Even with the STEM approach, mathematics remains more dominant than other disciplines; nevertheless, the activity plans developed here for learning mathematics with STEM robotics have the potential to support students' 21st-century skills.

The study reveals alternative strategies that can be used for preparing pre-service

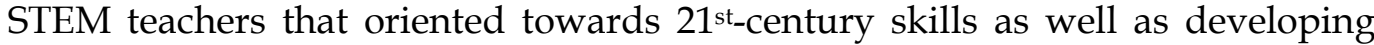
professional development for in-service teachers. STEM and robotics education is important to be part of the pre-service teacher's education curriculum, both standalone and integrated in the courses studied. They are also important to offer in the programme of in-service teachers' professional development. This fits with the era of the 4th industrial revolution that we are currently facing and accelerated with the pandemic era.

The lecture model, laboratory design, and online module are recommended for application and use in programmes to prepare future mathematics teachers. Next, implementing an activity plan and student worksheet in schools is needed to explore the impact of implementation on students' 21st-century skills. This will be done in the next step of this project. 


\section{Acknowledgements}

We would like to express gratitude to the LP2M UNNES for providing a DIPA research grant (Number: 158.23.4/UN37/PPK.3.1/2020. We would also like to thank teachers and prospective teachers who participated as research partners in our study.

\section{References}

Al Murshidi, G. (2019). STEM Education in the United Arab Emirates: Challenges and Possibilities. International Journal of Learning, Teaching and Educational Research, 18 (12), 316-332. https://doi.org/10.26803/ijlter.18.12.18

Altin, H., \& Pedaste, M. (2013). Learning approaches to applying robotics in science education. Journal of Baltic Science Education, 12(3), 365-377. http://www.scientiasocialis.lt/jbse/?q=node/302

Ananiadou, K., \& Claro, M. (2009) 21st Century Skills and Competences for New Millennium Learners in OECD Countries, OECD Education Working Papers, No. 41, OECD Publishing, Paris. https://doi.org/10.1787/218525261154

Barker, B. S., Nugent, G., \& Grandgenett, N. (2008). Examining 4-H robotics and geospatial technologies in the learning of science, technology, engineering, and mathematics topics. Journal of Extension, 46(3), 1.

Bicer, A., Capraro, R. M., \& Capraro, M. M. (2017). Integrated STEM Assessment Model. Eurasia Journal of Mathematics, Science and Technology Education, 13(7), 3959-3968. https:// doi.org/10.12973/eurasia.2017.00766a

Bergsten, C., \& Frejd, P. (2019). Preparing pre-service mathematics teachers for STEM education: an analysis of lesson proposals. ZDM, 51(6), 941-953. https://doi.org/10.1007/s11858-019-01071-7

Corlu, M. S., Capraro, R. M., \& Capraro, M. M. (2014). Introducing STEM education: Implications for educating our teachers in the age of innovation. Education and Science, 39(171), 74-85.

Christensen, C. M., \& Eyring, H. J. (2011). The innovative university: Changing the DNA of higher education from the inside out. John Wiley \& Sons.

English, L. D., \& King, D. T. (2015). STEM learning through engineering design: fourthgrade students' investigations in aerospace. International Journal of STEM Education, 2(1), 1-18. https:// doi.org/10.1186/s40594-015-0027-7

English, L. D. (2016). STEM Education K-12: Perspectives on integration. International Journal of STEM Education, 3(1), 1-8. https:// doi.org/10.1186/s40594-016-0036-1

English, L. D., \& King, D. (2019). STEM Integration in Sixth Grade: Designing and Constructing Paper Bridges. International Journal of Science and Mathematics Education, 17, 863-88. https://doi.org/10.1007/s10763-018-9912-0

Forsström, S. E., \& Kaufmann, O. T. (2018). A Literature Review Exploring the use of Programming in Mathematics Education. International Journal of Learning, Teaching and Educational Research, 17(12), 18-32. https://doi.org/10.26803/ijlter.17.12.2

Frejd, P. (2017). Mathematical modelling as a professional activity: Lessons for the classroom. In G.A. Stillman, W. Blum \& G. Kaiser (Eds.), Mathematical Modelling and Applications: Crossing and Researching Boundaries in Mathematics Education (pp. 371-388). Cham: Springer.

Gravemeijer, K., Stephan, M., Julie, C., Lin, F.-L., \& Ohtani, M. (2017). What mathematics education may prepare students for the society of the future? International Journal of Science and Mathematics Education, 15(1), 105-123. https://doi.org/10.1007/s10763-017-9814-6 
Groen, L., Coupland, M., Langtry, T., Memar, J. Moore, B., \& Stanley, J. (2015). The Mathematics Problem and Mastery Learning for First-Year, Undergraduate STEM Students. International Journal of Learning, Teaching and Educational Research, 11(1), 141-160.

Hafiz, N. R. M., \& Ayop, S. K. (2019). Engineering Design Process in STEM Education: A Systematic Review. International Journal of Academic Research in Business and Social Sciences, 9(5), 618-639. https://doi.org/10.6007/IJARBSS/v9-i5/5998

Holmlund, T. D., Lesseig, K., \& Slavit, D. (2018). Making sense of "STEM education" in K12 contexts. International Journal of STEM Education, 5(1), 32. https://doi.org/10.1186/s40594-018-0127-2

Honey, M., Pearson, G., \& Schweingruber, H. A.,(Eds.). (2014). STEM integration in K-12 education: Status, prospects, and an agenda for research (Vol. 500). Washington, DC: National Academies Press.

Jolly, A. (2016). STEM By Design: Strategies and Activities for Grade 4-8. Routledge.

Kertil, M., \& Gurel, C. (2016). Mathematical modeling: A bridge to STEM education. International Journal of Education in Mathematics Science and Technology, 4(1), 44-55.

Leung, A. (2019). Exploring STEM pedagogy in the mathematics classroom: A tool-based experiment lesson on estimation. International Journal of Science and Mathematics Education, 17(7), 1339-1358.

Li, Y., Schoenfeld, A. H., diSessa, A. A., Graesser, A. C., Benson, L. C., English, L. D., \& Duschl, R. A. (2019). Design and Design Thinking in STEM Education. Journal for STEM Education Research, 2(2), 93-104. https://doi.org/10.1007/s41979-01900020-z.

Lockledge, J. C., \& Salustri, F. A. (1999). Defining the engine design process. Journal of Engineering Design, 10(2). https://doi.org/10.1080/095448299261344

Mataric, M. J. (2004). Robotics education for all ages. MIT Press.

Mataric, M. J., Koenig, N. P., \& Feil-Seifer, D. (2007). Materials for Enabling Hands-On Robotics and STEM Education. In AAAI spring symposium: Semantic scientific knowledge integration, Stanford, March 2007. (pp. 99-102).

National Research Council. (2011). Successful STEM Education: A Workshop Summary. The National Academies Press. https://doi.org/10.17226/13230

Nugent, G., Barker, B., Grandgenett, N., \& Adamchuk, V. I. (2010). Impact of robotics and geospatial technology interventions on youth STEM learning and attitudes. Journal of Research on Technology in Education, 42(4), 391-408.

OECD. (2019). PISA 2018 Results (Volume I): What Students Know and Can Do. OECD Publishing. https://doi.org/10.1787/5f07c754-en

Rackov, M., \& Knežević, I. (2017). Aspects of the Engineering Design Process, in Proceeding of The XVII International Scientific Conference on Industrial Systems 2017, pp. 344-349. University of Novi Sad.

Razali, F., Manaf, U.K.A., \& Ayub, A.F.M. (2020). STEM Education in Malaysia towards Developing a Human Capital through Motivating Science Subject. International Journal of Learning, Teaching and Educational Research, 19(5), 411-422.

Siew, N. M. (2017). Integrating STEM in an Engineering Design Process: The Learning Experience. The Eurasia Proceedings of Educational \& Social Sciences (EPESS), 6(4), 128-141.

Soland, J., Hamilton, L. S., \& Stecher, B. M. (2013). Measuring 21st Century Competencies Guidance for Educators. Asia Society Global Cities Education Network.

Stebbins, R. (2001). Exploratory Research in the Social Sciences. SAGE Publications, Inc. https://doi.org/http://dx.doi.org/10.4135/9781412984249 
Stohlmann, M. S., Roehrig, G. H., Moore, T. J., \& Green, S. L. (2014). The Need for STEM Teacher Education Development. In Green, S.L. (Eds.), STEM Education: How to Train 21st Century Teachers (pp. 17-32). Nova Science.

Syukri, M., Soewarno, S., Halim, L., \& Mohtar, L. E. (2018). The impact of engineering design process in teaching and learning to enhance students' science problemsolving skills. Jurnal Pendidikan IPA Indonesia, 7(1), 66-75. https://doi.org/10.15294/jpii.v7i1.12297

Vasquez, J. A., Sneider, C., \& Comer, M. (2013). STEM Lesson Essentials: Integrating science, technology, engineering, and mathematics. Heinemann.

Yata, C., Ohtani, T., \& Isobe, M. (2020). Conceptual framework of STEM based on Japanese subject principles. International Journal of STEM Education, 7(1), 1-10. https:// doi.org/10.1186/s40594-020-00205-8

Yiannoutsou, N., Nikitopoulou, S., Kynigos, C., Gueorguiev, I., \& Fernandez, J. A. (2017). Activity Plan Template: A Mediating Tool for Supporting Learning Design with Robotics. In M. Merdan, W. Lepuschitz, G. Koppensteiner \& R. Balogh (Eds.), Robotics in Education (pp. 3-13). Springer International Publishing. 